\title{
ANALYSIS OF FORMALDEHYDE PRESERVATIVES IN WET ANCHOVY (Stolephorus Sp.) FROM TRADITIONAL MARKETS IN MAKASSAR CITY, SOUTH SULAWESI
}

\author{
Adriani $^{1^{*}}$, Abd. Karim ${ }^{1}$, Seniwati Dali ${ }^{1}$ \\ ${ }^{1}$ Department of Chemistry, Faculty of Mathematics and Natural Sciences, University of \\ Hasanuddin Jl. Perintis Kemerdekaan Km. 10 Makassar 90245
}

\begin{abstract}
Abstrak. Pengawet makanan merupakan bahan sangat penting dalam peningkatan kualitas dan produksi makanan olahan yang dapat memperpanjang umur simpan makanan tersebut. Namun demikian terdapat berbagai macam pengawet dan diantaranya pengawet yang tidak diperbolehkan seperti formaldehida. Penelitian ini bertujuan untuk mengetahui kandungan bahan pengawet formaldehida pada ikan teri (stolephorus sp.) basah dari pasar tradisional Kota Makassar Sulawesi Selatan. Bahan pengawet formaldehida diidentifikasi dengan melalui uji kualitatif dan kuantitatif. Uji kualitatif formalin menggunakan pereaksi Schryver dengan menggunakan metode analisis Spektrofotometer UV-Vis. Hasil analisis kualitatif menunjukkan bahwa semua sampel ikan teri basah mengandung formaldehida, dengan nilai konsentrasi Sampel dari Pasar Daya A; Pasar Daya B; Pasar Daya C berturut-turut 0,2702ppm; 0,1307ppm; 0,0871ppm, Pasar Antang A; Pasar Antang B; Pasar Aantang C berturut-turut 0,1612ppm; 0,2223ppm; 0,1525ppm, Pasar Pa'baengbaeng A; Pasar Pa'baeng-baeng B; Pasar Pa'baeng-baeng $\mathrm{C}$ berturut-turut 0,1918ppm; 0,0087ppm; 0,2877ppm, Pasar Terong A; Pasar Terong B; Pasar Terong C; berturut-turut 0,1394ppm; 0,1961 ppm; 0,0043. Kadar formaldehida terendah terdapat pada Pasar Terong C dengan kadar 0,0087ppm dan kadar formaldehida tertinggi terdapat pada Pasar Pa'baeng-baeng $\mathrm{C}$ dengan kadar 0,2877ppm.
\end{abstract}

Kata Kunci : Formaldehida, Pengawet, Pereaksi Schryver, Spektrofotometer Uv-Vis

Abstract. Food preservatives are very important ingredients in improving the quality and production of processed foods. However there are various presenvatives and such preservatives such as formaldehide are not allowed. This study aims to determine the content of preservatives in fresh anchovy (stolephorus sp.) from the traditional market of Makassar City South Sulawesi. Formaldehyde preservatives is identified by qualitative and quantitative test, qualitative formaldehyde was tested using Schryver reagent using UV-Vis Spectrophotometer analysis method. The result of qualitative analysis showed that all samples contained formaldehyde, with the concentration value of 0.2702ppm; 0.1307ppm; 0.0871ppm in Daya Market A; Daya Market B; Daya Market C samples, respectively. The content of 0.1612ppm; 0.2223ppm; 0,1525ppm in Antang Market A; Antang Market B; Antang Market C samples, respectively. The content of 0,1918ppm;0,0087ppm; 0.2877ppm in Terong Market A; Terong Market B; Terong Market C, samples, respectively and the content of $0.1394 \mathrm{ppm} ; 0.1961 \mathrm{ppm} ; 0,0043$, in Pa'baeng-baeng Market A; Pa'baeng-baeng Market B; Pa'baeng-baeng Market C samples, respectively. The lowest formaldehyde level was found in Terong Market $\mathrm{C}$ with level of $0.0087 \mathrm{ppm}$ and the highest formaldehyde level was in Pa'baeng-baeng Market $\mathrm{C}$ with the level of $0.2877 \mathrm{ppm}$.

Keywords : Formaldehyde, Preservatives, Schryver Reagent, UV-Vis Spectrophotometer 


\section{INTRODUCTION}

Fresh anchovy is one of the fish that has a high protein content, which is 68.7 $\mathrm{g} / 100 \mathrm{~g}$ of fresh dried anchovy and 42 $\mathrm{g} / 100 \mathrm{~g}$ of salted dried anchovy. Anchovy protein contains a number of essential amino acids, namely amino acids that cannot be formed in the body, but must come from food. The most prominent essential amino acids in anchovy are isoleucine, leucine, lysine and valine. Besides containing essential amino acids, anchovies are also rich in non-essential amino acids. The prominent non-essential amino acids in anchovy are glutamic acid and aspartic acid, each of which reaches 1,439 and

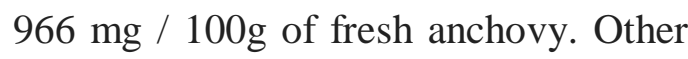
nutrients that are very meaningful from anchovy are minerals, calcium, phosphorus and iron (Sastra, 2008).

Fresh fish has the characteristics of being easily damaged and easily rot so it needs to be preserved. Preservation which is commonly used by the community is by cooling, drying and adding certain substances. Substances added to fish can be either natural or artificial substances. Based on the Minister of Health Regulation No.1168 /MENKES/PER/X/1999 the additional ingredients allowed for food are $\mathrm{NaCl}$ salt, sodiumtripolyphosphate (STPP), granulated sugar, sodium nitrite, sodium lactate, sodium acetate, and compounds (potassium nitrate, calcium nitrate, sodium nitrate). People generally do not use these substances for fear of changing the taste of the ingredients to be preserved. They choose prohibited synthetic preservatives such as formaldehyde, because prices are relatively cheap, easy to obtain and their use does not require special expertise. The principle of preservation is to maintain fish as long as possible by inhibiting or stopping the activity of decomposing microorganisms. Preservation of fish will cause changes in the characteristics of fresh fish, both smell, taste, shape, and texture of the meat (Sutarni, 2013).

Formaldehyde that enters the body in amounts of $1.5 \mathrm{mg}$ to $14 \mathrm{mg}$ per day or in $0.1 \mathrm{ppm}$ solution can be tolerated, if it exceeds the threshold it can cause interference with the organs and systems of the human body. The resulting consequences can occur in a short or short term and in the long term, through inhalation, direct contact or ingestion (Hastuti, 2010).

Wulan (2015) analyzed formaldehyde from 10 meatball samples by Uv-Vis spectrophotometer with Schryver reagents in Panakukkang District and the results were identified as many as 4 meatball samples which showed positive results with different levels of $0.357 \mu \mathrm{g} / \mathrm{g}, 0.285 \mu \mathrm{g} / \mathrm{g}, 1.504$ $\mu \mathrm{g} / \mathrm{g}$ and $1.070 \mu \mathrm{g} / \mathrm{g}$. Faradillah et al (2014) identified formaldehyde using a Uv-Vis spectrophotometer with Nash reagents on meatballs sold in Padang City. The results showed that 20 out of $42(47.6 \%)$ samples taken from traders of meatball carts, meatball stalls, and restaurants contained formaldehyde. Putri et al. (2016) tested the formaldehyde content by Uv-Vis

${ }^{1}$ Corresponding author:

adrianimuharif@yahoo.co.id 
spectrophotometer with Schiff reagents on papaya (carica papaya L.) and pineapple (ananas comosus L.) fruit sold in the Raden Fatah State Islamic University Palembang and showed that all samples were tested containing formaldehyde with levels of $0.0007 \mathrm{ppm}$ and $0.0025 \mathrm{ppm}$.

Abdullah (2013) has tested the content of formaldehyde by spectrophotometer with Scrhyver reagent on salted anchovy from the Market of Tuesday, Central and Galael of Gorontalo City and shows that the sample contains formaldehyde. Analysis of formaldehyde content by UvVis spectrophotometer with Nash reagent on sunu fish from the Traditional Makassar Market by Riana (2015) also showed the presence of formaldehyde in the samples analyzed. Based on the previous description of the abuse of formaldehyde from various types of food, a study was conducted on the analysis of formalidehyde preservatives carried out on wet anchovy from the Traditional Market of Makassar City.

\section{MATERIAL AND METHOD Instruments}

The instrument used are label paper, stationery, destilator, pumpkin distillate, $100 \mathrm{~mL}$ volumetric flask, $50 \mathrm{~mL}$ and 10 $\mathrm{mL}$, UV-Vis spectrophotometer, and glassware commonly used in laboratories.

\section{Materials,}

The materials used were samples of wet anchovy, $85 \%$ phosphoric acid $\left(\mathrm{H}_{3} \mathrm{PO}_{4}\right)$, concentrated hydrochloric acid (HCl), Potassium Ferrisianide (III) $\left(\mathrm{K}_{3} \mathrm{Fe}(\mathrm{CN})_{6}\right)$, phenylhydrazine, aquades, $37 \%$ formaldehyde, filter paper.

\section{Methods}

\section{Sampling technique}

Wet anchovy is taken from 4 different locations, namely 3 samples from Traditional Eggplant, Pa'baengbaeng, Antang and Daya markets. Wet anchovy samples taken from each trader of wet anchovy are packed in containers such as dry plastic. Plastic containers are coded. After that, samples of wet anchovy are taken from the sampling site to be carried out in the laboratory testing stage.

\section{Formaldehyde Analysis Qualitative Test of Formaldehyde Compounds in Wet Anchovy Samples with Schryver Reagents}

Twelve different samples of wet anchovy were mashed, each weighed as much as $30 \mathrm{~g}$, then the sample was put into a distillation flask and added $200 \mathrm{~mL}$ of distilled water. Then acidified with $85 \%$ phosphoric acid solution of $10 \mathrm{~mL}$. The solution is slowly distilled piped, put into a test tube and added Schryver reagent $(2 \mathrm{~mL}$ phenylhydrazine hydrochloride $1 \%, 5 \mathrm{~mL}$ concentrated $\mathrm{HCl}$ and $\left.1 \mathrm{~mL} \mathrm{~K}_{3} \mathrm{Fe}(\mathrm{CN})_{6}\right)$. The solution will turn red if it contains formaldehyde in the sample (Riana, 2015).

\section{Quantitative Test of Formaldehyde Levels on Wet Anchovy Samples with Spectrophotometric Methods}

Making the mother liquor and standard, Formaldehyde $37 \%$ with different concentrations. Then the solution is put into a test tube that has been labeled, added Schryver reagent which is $1 \%$ phenylhydrazine hydrochloride as much as $2 \mathrm{~mL}, 5 \mathrm{~mL}$ concentrated $\mathrm{HCl}$ and $1 \mathrm{~mL} \mathrm{~K}_{3} \mathrm{Fe}(\mathrm{CN})_{6}$ at 
each different concentration, Samples that are positive in qualitative testing, measured the absorbance with spectrophotometer at a wavelength of 518 nm (Riana, 2015).

\section{Determination of Calibration Curves}

\section{Making 1000 mL Formalin 1000 ppm}

Formalin solution $37 \%$ pipetted as much as $2.70 \mathrm{~mL}$ into a $1000 \mathrm{~mL}$ volumetric flask, added with distilled water, diluted to reach the boundary mark, homogenized.

\section{Making $100 \mathrm{~mL}$ Formalin 10 ppm}

Standard Solution 1000 ppm formalin mother liquor pipetted as much as $5 \mathrm{~mL}$ into a $50 \mathrm{~mL}$ volumetric flask, added with aquades, diluted to the boundary mark, homogenized.

Making $10 \mathrm{~mL}$ Formalin Standard Solution $0.2 \mathrm{ppm}, 0.4 \mathrm{ppm}, 0.8 \mathrm{ppm}$, $0.16 \mathrm{ppm}$ and $0.32 \mathrm{ppm}$

The $10 \mathrm{ppm}$ formalin standard solution is piped as much as $0.1 \mathrm{~mL}, 0.2$ $\mathrm{mL}, 0.4 \mathrm{~mL}, 0.8 \mathrm{~mL}$ and $1.6 \mathrm{~mL}$ into a $10 \mathrm{~mL}$ volumetric flask, added with distilled water, diluted to the boundary mark, homogenized. Then each standard series solution is piped as much as $10 \mathrm{~mL}$ into a test tube, Scrhyver reagent is added, which is phenylhydrazine hydrochloride $1 \%$ as much as $2 \mathrm{~mL}, 5$ $\mathrm{mL}$ concentrated $\mathrm{HCl}$ and $1 \mathrm{~mL}$
$\mathrm{K}_{3} \mathrm{Fe}(\mathrm{CN})_{6}$. Then the absorbance is measured.

\section{Making a blank solution}

Aquadest solution pipetted as much as $10 \mathrm{~mL}$ into a test tube, added Schryver reagent namely phenylhydrazine $\mathrm{HCl}$ $1 \%$ as much as $2 \mathrm{~mL}, 5 \mathrm{~mL}$ concentrated $\mathrm{HCl}$ and $1 \mathrm{~mL} \mathrm{~K}_{3} \mathrm{Fe}(\mathrm{CN})_{6}$. Then the absorbance is measured.

\section{EXPERIMENTAL RESULT}

Qualitative Test Results for Formaldehyde Preservatives with Schryver reagents

Qualitative analysis of formaldehyde in wet anchovy samples can use several methods such as Nash reagent method, chromatoprat acid reagent method and Schryver reagent method (Suryadi et al, 2008). According to Schryver (1910) identification of formaldehyde by using the Schryver reagent method can be done by adding a solution of $2 \mathrm{~mL}$ fennilhydrazine hydrochloride solution, $1 \%$ potassium ferricianide solution of $1 \mathrm{~mL}, 5 \mathrm{~mL}$ concentrated hydrochloric acid into $10 \mathrm{~mL}$ of the material which will tested where if the food is tested. If react with formaldehyde will change color from colorless to bright red then its absorption is measured at a wavelength of $518 \mathrm{~nm}$. The results of the qualitative analysis of formaldehyde with Schryver reagent on wet samples of anchovy (Stolephorus sp.) From the Makassar Traditional Market can be seen in Table 1 . 
Table 1. Results of Qualitative Formaldehyde Test Analysis with Schryver Reagen

\begin{tabular}{|c|c|c|c|}
\hline \multicolumn{2}{|l|}{ Sample } & $\begin{array}{c}\text { reagent Color Test } \\
\text { Schryver }\end{array}$ & Results \\
\hline \multirow{3}{*}{ Daya Marker } & PD A & Red & + \\
\hline & PD B & Red & + \\
\hline & PD C & Red & + \\
\hline \multirow{3}{*}{ Antang Market } & PA A & Red & + \\
\hline & PA B & Red & + \\
\hline & PA C & Red & + \\
\hline \multirow[t]{3}{*}{ Pa'baeng-baeng Market } & PP A & Red & + \\
\hline & PP B & Yellow & + \\
\hline & PP C & Red & + \\
\hline \multirow{3}{*}{ Terong Market } & PT A & Red & + \\
\hline & PT B & Red & + \\
\hline & PT C & Yellow Chocolate & + \\
\hline
\end{tabular}

\section{Information:}

$+\quad=$ Positive contains formaldehyde

- $\quad=$ negative containing formaldehyde

$\mathrm{PD} \quad=$ Daya Market

$\mathrm{PA} \quad=$ Antang Market

PP $=$ Pa'baeng-Baeng Market

PT = Terong Market

The prediction of the chemical reaction between formalin and Schryver reagent can be seen in Figure 1.

Based on the qualitative test of formaldehyde on anchovy (Stolephorus $s p$.) Wet in several Traditional Markets in Makassar City using the Schryver reagent method all samples showed that the sample contained formaldehyde, but 2 samples had very little formaldehyde so that the color produced differed from 10 other samples. This study is similar to the research conducted by Nuryahya (2015) on qualitative and quantitative analysis of formaldehyde content in some fresh fish 11 of the 12 samples tested positive for formalin and 1 sample that did not contain formaldehyde. Research on formaldehyde analysis in fresh fish with Schryver reagents conducted by Wicaksono (2011) from Pasar Minggu shows the presence of formaldehyde in samples with an average level of $888.32 \mu \mathrm{g} / \mathrm{g}$. In addition, a study conducted by Yuaninda (2012) on formaldehyde testing in several markets in the Banten region showed that the fish observed had a very high formaldehyde content that exceeded the concentration value of formaldehyde solution which was equal to $3.75 \mathrm{ppm}$ which had a value of 0.032 , the formaldehyde content not good for consumption. In general, the safe threshold of formaldehyde in foods that can still be tolerated in an adult's body is $1.5 \mathrm{mg}$ up to $14 \mathrm{mg}$ per day whereas formaldehyde in the form of water drink which can still be tolerated in the body which is $0.1 \mathrm{ppm}$ (Singgih, 2013). 

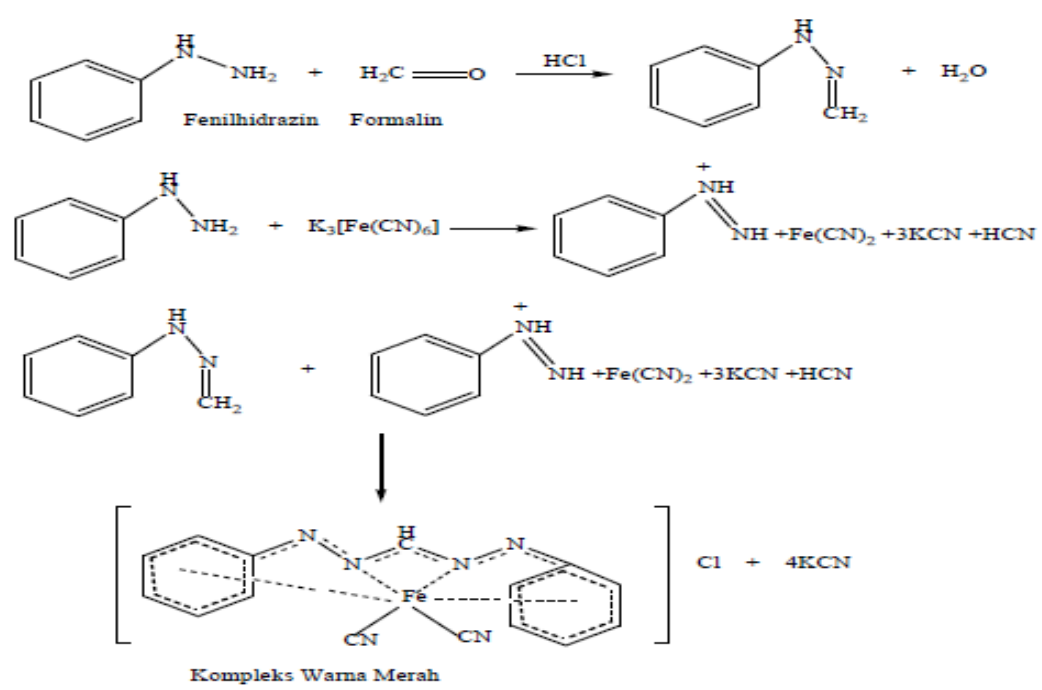

Figure 1. Formaldehyde reaction with Schryver Reagent

Material Quantitative Test Results Formaldehyde Preservatives With Using the method UV-Vis Spectrophotometer

First step on this research is determination maximum wavelength from formaldehyde standard series solution reacted with reagents modified by Schryver explains the reaction the chemical that occurs is condensation reaction between formaldehyde with phenylhydrazine forming phenylhydrazone, where in the presence of oxidizers will resulting in a reaction oxidation that produces a wet weak. Then wet is weak in the presence of strong acids excess will produce salt which can experience dissociation hydrolytic in dilution (Walter, 1996).

Oxidizing agent used by Schryver (1910) is potassium ferrisianide where in large quantities produce relatively stable colors, and by using concentrated hydrochloric acid as an acidic agent so that this method can be done for quantitative tests. This reagent consisted of $2 \mathrm{~mL}$ of $1 \%$ phenylhydrazine hydrochloride solution, $1 \mathrm{~mL}$ of potassium ferricianide solution, and 5
$\mathrm{mL}$ of concentrated hydrochloric acid, the presence of formaldehyde in the test solution was shown in bright red so that it could be used to measure formaldehyde using UV-Vis spectrophotometer. Color complex stability can only be maintained for 2 hours after the color complex is formed in an acidic state. Therefore, measuring levels using a spectrophotometer no more than 2 hours after the complex is formed (Azas, 2013).

Linear regression analysis $\mathrm{y}=\mathrm{ax}+$ b. ideal linear relationship is achieved if $\mathrm{r}^{2}=1$ or close to 1 (Harmita, 2006). The preparation for the formalin calibration curve is done by making a standard series of various measurement concentrations namely $0.02 \mathrm{ppm}, 0.04$ ppm, 0.08 ppm, 0.16 ppm, 0.32 ppm and then measuring its absorption at a wavelength of $512 \mathrm{~nm}$. The formalin standard calibration curve can be seen in Figure 2. The calibration curve obtained a regression equation $\quad \mathrm{y}=0.2294 \mathrm{x}$ +0.02 with keophysisen $\left(r^{2}\right)$ of 0.9625 . The acceptance criteria of the correlation coefficient are $\left(r^{2}\right)$ of $\geq 0.9999$ Harmita (2006) which means that the results of 
the curve between absorbance and concentration have a linear relationship.

The calibration curve is then used to calculate quantitative parameters. Quantitative is a parameter in microscopic analysis and is interpreted as the smallest quantity of analytes in a sample that can still meet the criteria carefully and carefully. Quantity can be calculated statistically through a linear regression line from the calibration curve. The measurement value will be the same as the value of $a$ in the liner line equation $y=a x+b$ (Harmita, 2006). The quantity can be calculated statistically from the calibration curve. The measurement value will be the same as the value of $a$ in the linear line equation $y=a x+b$ (Harmita, 2006).

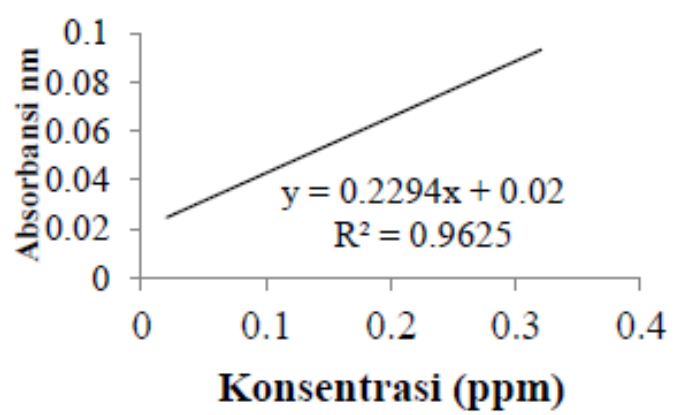

Figure 2. Formalin standard series calibration curve

Obtained line equation $\mathrm{y}=0.2294 \mathrm{x}$ +0.02 to calculate the formaldehyde level in the sample. The samples that were analyzed quantitatively using a $\mathrm{UV}-\mathrm{V}$ is spectrophotometer were positive samples containing formaldehyde based on the results of a qualitative test, with different levels, samples from PD A; PD B; PD C with levels of $0.2702 \mathrm{ppm} ; 0,1307 \mathrm{ppm}$; 0.0871 ppm, PA A; PA B; PA C with levels of $0.1612 \mathrm{ppm} ; 0.2223 \mathrm{ppm}$; 0.1525 ppm, PP A; PP B PP C with levels of $0.1918 \mathrm{ppm}$; 0,0087 ppm; 0.2877 ppm, PT A; PT B; PT C with levels of $0.1394 \mathrm{ppm} ; 0.1961 \mathrm{ppm}$; $0.0043 \mathrm{ppm}$.

The lowest formaldehyde level was found in PT C with levels of 0.0043 ppm and the highest formaldehyde level was found in PP C with a level of 0.2877 ppm. The American Conference of Governmental and Industrial Hygienists
(ACGIH) set the safe threshold of formalin in the body is $0.4 \mathrm{ppm}$ (Alsuhendra and Ridawati, 2013). Whereas according to IPCS (International Program on Chemical Safety, that in general the safe threshold of formaldehyde in food that can still be tolerated in the adult body is $1.5 \mathrm{mg}$ to $14 \mathrm{mg}$ per day while formaldehyde in the form of drinking water can still be tolerated in the body, namely $0,1 \mathrm{ppm}$ (Singgih, 2013) The smallest formaldehyde level in the sample is $0,0087 \mathrm{ppm}$, so based on the tolerance limit of formaldehyde that can be accepted by the body in 1 day, and 9 other samples more than $0,1 \mathrm{ppm}$ the sample of wet anchovy tested in the category is not safe for consumption The results of the determination of 
formaldehyde levels in all samples can be seen in Figure 3.

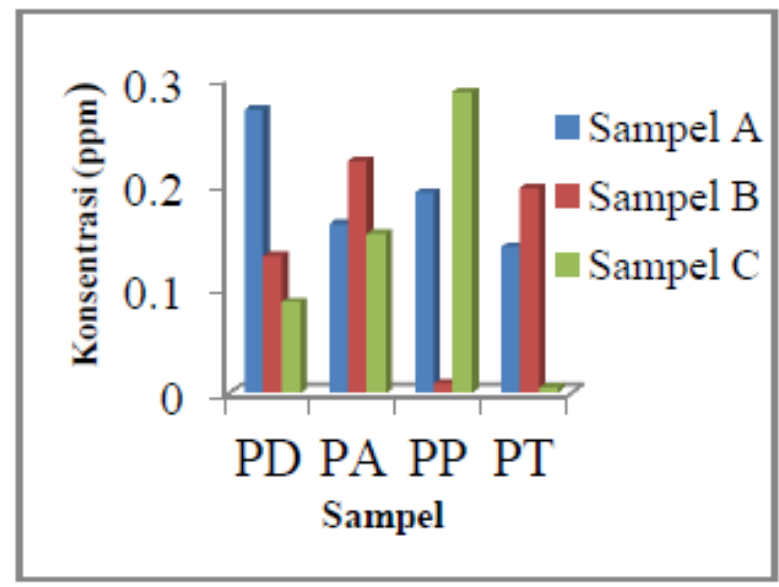

Figure 3. Graph analysis of formaldehyde levels in wet anchovy samples

\section{CONCLUSION}

Based on the results of the study it can be concluded that the wet anchovy sold in the Makassar Traditional Market with a qualitative test analysis of all samples of wet anchovy positively contains formaldehyde. The lowest level of formaldehyde is found in Terong Market sample $\mathrm{C}$ with a concentration of 0.0087 ppm. the highest body and formalin levels were found in Pa'baeng-baeng Market, sample C with a level of $0.2877 \mathrm{ppm}$, not safe for consumption.

\section{REFERENCES}

Abdullah, S., 2013, Qualitative Test of Formalin content in Salted Fish sold in Central Market of Gorontalo City, unpublished Skipsi, Faculty of Mathematics and Natural Sciences, Gorontalo State University.

Afrianto, E., and E. Liviawaty., 1991, Fish Preservation and Processing, Kanisius, Yogyakarta.

Allport, N.L., 1951, Colorimetric Analysis, Hall Chapman, New York.

Alsuhendra and Ridawati, 2013, Toxic In Food, Bandung: PT. Teen Rosdakarya.
Aryati, E.E., Wulan, A., and Darmayanti, S., 2014, Benefits of Fresh Anchovy (Stolephorus Sp) on Bone and Dental Growth, Journal of Odontodental, 1 (2): 52-58.

Astawan, and Made., 2006, Getting to Know Formalin and Its Risks, Penebar Swadaya, Jakarta.

Azas, Q.S., 2013, Analysis of Borax Levels in Dates Fruit Circulating in Tanah Abang Market Using UV-Vis Spectrophotometer, Thesis not Published, Pharmacy Study Program, Faculty of Medicine and Health Sciences, Syarif Hidayatullah State Islamic University, Jakarta.

Borgstrom, G., and Paris, C.D., 1965. The Regional Development of Fisheries and Fish Processing, Fish as Food, Academic Press, New York.

Cahyanto, 2008, Spectrophotometer Review. Xains Info, http: // xains info.blogspot.com/ 2008/08 / reviewspectrophotometer. html (online), accessed on February 22, 2017.

Constantinides, 1988, Applied numerical methods with Personal Computers, MC Grawhill Book Company, New York. 
Day, R.A and Underwood, A.L., 1999, Analysis of Quantitative Chemistry, Erlangga, Jakarta.

Indonesian Ministry of Health, 1995, Indonesian Pharmacopoeia, Edition IV, Jakarta.

Dwiari, S. R., 2008, Food Technology, Ministry of National Education, Jakarta.

Eka, R., 2013, Secrets of Knowing Dangerous Foods, Titik Media Publisher, Jakarta.

Endah, I., Saraswati, T.R., and Nurani., 2013, Effects of Formalin, Diazepam and Alcoholic Beverages on Feed Consumption, Drinking and Mus Musculus Body Weight, Journal of Science and Mathematics, 17 (3): 141144.

Fadli, R.A., Ibrahim, M.N., and Sadirmantara, M.S, 2016, Analysis of Formalin Preservative Substances in Terasi Traded in Kendari Traditional Market, Food Science and Technology Journal, 1 (1): 73-78.

Faradilah., Alioes, Y., and Elmatris., 2014, Identification of Formaldehyde in Meatballs sold in several Places in the City of Padang, Andalas Health Journal, 3 (2): 2301-7406.

Hadi, A., 2009, Spectrophotometry, Tjah Kimai, Semarang State University, Semarang.

Harjono, Y., 2006, Healthy Living Healthy Eating, Kompas, Jakarta.

Harmita., 2006, Quantitative Analysis of Raw Materials and Pharmaceutical Preparations, Pharmacy Department of FMIPA Universitas Indonesia, Jakarta.

Hastuti, S， 2010， Qualitative and Quantitative Analysis of Formaldehyde in Salted Fish in Madura, Journal of Agrointek, 4 (2): 132-137.

Horwitz, W., 1970, Official Method of Analysis of Official Analytical Chemist, Fifteenth Edition, Washington DC.

Hutomo, M., Burhanuddin, A. Djamali, and Martosewojo S., 1987, Anchovy Resources in Indonesia, Oceanology
Research and Development Center LIPI, Jakarta.

Khopkar, 1990, Basic Concepts of Analytical Chemistry, UI Press, Jakarta.

Kuswan, U.S., 2011, Optimization of Scryver Reagent and Its Application to Formaldehyde Analysis in Intestine and Chicken Liver Samples by Spectropometry, Thesis Not Published, Pharmacy Study Program, Faculty of Mathematics and Natural Sciences, University of Indonesia, Depok.

Mayrita, 2010, Optimizing the Utilization of Anchovy in Banten Bay, Bogor (IDN), Unpublished Thesis, Fisheries and Marine Sciences, Bogor Agricultural Institute.

Nuryahya, R.A., 2015, Qualitative and Quantitative Test of Formalin Levels in Fresh Fish, Jurnal Perikanan, 4 (2); 1-30.

Minister Regulation, 1999, Food Additives, Regulation of the Minister of Health of the Republic of Indonesia number 1168 / Menkes / Per / X / 1999, Jakarta.

Putri, DA, Pane, ER, and Khasianturi, V., 2016, Test for Formalin in Papaya (Carica Papaya L.) and Pineapple Fruit (Ananas Comosus L.) which are sold in Palembang's Uin Raden Fatah Environment with Spectrophotometry Method, Journal Biota, 2 (1): 76-81.

Riana, 2015, Formalin Content and Salt Content in Sunu Asin Fish from Makassar, South Sulawesi Traditional Markets, Unpublished Thesis, Veterinary Medicine, FK, Hasanuddin University.

Roth, J., 1988, Pharmaceutical Chemistry, Ellishorwood, Singapore.

Schryver, S.B., 1910, The Photochemical Formation of Formaldehyde in Green Plants, Procroy Soc Series, London.

Singgih, H, 2013, Formalin Test, ELTEK Polytechnic Negri Malang Journal, 11 (1), 11-17.

Sumarauw, W., Fatimawali., And Yudistira, A., 2013, Identification and Determination of Benzoic Acid Levels 
in Soy Sauce Circulating in the City of Manado, Pharmaceutical Scientific Journal, 2 (1): 2302-2493.

Surawidjaja, 1994, Calibration Matrix for Determination of Component Concentration in Mixed Solutions, FMIPA, Yogyakarta.

Suryadi H., Kurniadi M., and Melanie Y., 2010, Formalin Analysis in Fresh Fish and Shrimp Samples from Muara Angke Market, Pharmaceutical Science Magazine, 7 (3): 16-31.

Suryadi, H., Mansur, U and Christine, N., 2008, Optimization of Schryver Reagents for Formalin Identification in Candy Samples, XVI Scientific Congress of the Indonesian Pharmacy Bachelor Association, Yogyakarta.

Suryana A. 1993. Impact of the Use of Preservatives on Food and Its Supervision, Diponegoro University, Semarang.

Sutarni, 2013, Factors Affecting the Preservation of Salted Teri Fish in Labuhan Maringgai District, East Lampung Regency. Pharmaceutical Scientific Journal, 7 (1): 20-24.

Syafitri M., 2007, Management of Export Fish Production at PT. Tridaya Eramina Bahari Muara Baru Jakarta, Unpublished Thesis, Bogor (IDN), Department of Fisheries Resource Utilization. Faculty of Fisheries and Marine Sciences, Bogor Agricultural University.

Theines, C.H., and Haley, T.J., 1955, Clinical Toxicology, 3rd Edition, Lea $\&$ Febiger, Philadelphia.

Wicaksono, S.S., 2011, Formalin Analysis in Fresh Fish and Shrimp with Schryver Reagent, Thesis Not Published, Pharmacy Study Program, Faculty of Mathematics and Natural Sciences, University of Indonesia, Depok.

Widodo, J., 2006, Effect of Formalin on Body Systems, Center for Biotechnology Development, Muhammadiyah University, Malang.

Winarno F.G., 2004, Food Safety Volume 1, M-Brio Press, Bogor.
Wulan, S.R.S., 2015, Identification of Formalin in Meatballs from Meatball Traders in Panakukkang District, Makassar City, Thesis not Published, Veterinary Medicine Program, FK, Hasanuddin University, Makassar.

Yuaninda, A., 2014, Qualitative and Quantitative Test of Formalin Levels in Fresh Fish, Jurnal Perikanan, 6 (3); 6-11.

Minister Regulation, 1999, Food Additives, Regulation of the Minister of Health of the Republic of Indonesia number 1168 / Menkes / Per / X / 1999, Jakarta. 